\title{
Lobbying on audit regulation at IAASB ${ }^{\star}$
}

\author{
Thiago Macedo Pereira de Matos
}

Universidade Federal do Rio de Janeiro, Faculdade de Administração e Ciências Contábeis, Programa de Pós-Graduação em Ciências Contábeis, Rio de Janeiro, RJ, Brazil

Email: thiagompmatos@gmail.com

\section{Odilanei Morais dos Santos}

Universidade Federal do Rio de Janeiro, Faculdade de Administração e Ciências Contábeis, Departamento de Ciências Contábeis, Rio de Janeiro, RJ, Brazil

Email: odilanei@facc.ufrj.br

\section{Adriano Rodrigues}

Universidade Federal do Rio de Janeiro, Faculdade de Administração e Ciências Contábeis, Departamento de Ciências Contábeis, Rio de Janeiro, RJ, Brazil

Email: adriano@facc.ufrj.br

\section{Rodrigo de Oliveira Leite}

Universidade do Estado do Rio de Janeiro, Faculdade de Administração e Finanças, Departamento de Ciências Contábeis, Rio de Janeiro, RJ, Brazil

Email: rodrigo.de.oliveira.leite@gmail.com

Received on 09.19.2016 - Desk acceptance on 11.11.2016 - $4^{\text {th }}$ version approved on 11.08.2017 - Ahead of print on 02.22.2018

\begin{abstract}
The main goal of the paper is to analyze whether the positions of auditors and regulators, and their respective coalitions, regarding the proposals of the International Auditing and Assurance Standards Board (IAASB) in the last phase of the public consultation "Improving the Auditor's Report" are significantly different, as well as the effectiveness of a lobbying strategy using comment letters. The relevance of this research lies in providing evidence on whether or not the IAASB is influenced by the lobbying strategies of different interest groups carried out via comment letters, especially auditors and regulators (both individually and in coalitions). The results show that both auditors and regulators attempeted to influence the IAASB's decision-making process, with their coalitions taking a different position on some questions. However, none of these interest groups predominated in terms of the effectiveness of the lobbying carried out, hence the results are consistent with institutional theory, in that the IAASB seeks legitimacy in its actions and tries to accommodate several different interests, but does not let itself be captured by any specific group. We analyzed and classified the comments (from a total of 86 letters) to nine questions proposed by the IAASB into a five-point Likert scale. This classification was independently cross-validated by a second researcher. We applied ANOVA tests to analyze the position of the interest groups, and chi- squared tests for the position of their coalitions. This paper addresses lobbying within the process of auditing standards settings, thus expanding the current literature on lobbying in accounting, which is mainly restricted to accounting regulations. It also contributes methodologically by using a new five-point scale for the dependent variable instead of the usual binary approach.
\end{abstract}

Keywords: lobby, regulation, audit, auditor's report, IAASB.

Correspondence address:

Thiago Macedo Pereira de Matos

Universidade Federal do Rio de Janeiro, Faculdade de Administração e Ciências Contábeis, Programa

de Pós-Graduação em Ciências Contábeis

Avenida Pasteur, 250, sala 250 - CEP 22290-902

Urca - Rio de Janeiro - RJ - Brazil

*Article presented at the X ANPCONT Congress, Ribeirão Preto, SP, Brazil, June 2016. 


\section{INTRODUCTION}

Auditors communicate with users of accounting statement via their reports, thus enabling their use as a tool for reducing informational asymmetry in relation to company managers.

In Brazil, auditing is carried out in accordance with the Brazilian Accounting Standards - Auditing Techniques (NBC TA), published by the Federal Accounting Council (CFC), which have been aligned with the International Standards on Auditing (ISA) published by the International Auditing and Assurance Standards Board (IAASB) since 2010 and already adopted by more than 100 jurisdictions (International Federation of Accountants - IFAC, 2015a).

The IAASB is an international standard setter, supported by the International Federation of Accountants (IFAC) and focused on issuing and implementing international auditing standards, reviewing, quality control, assurance, and other services related to the auditing activities.

The development process for the standards published by the IAASB includes obtaining insights from a wide range of stakeholders, by issuing Exposure Drafts (ED) and other public consultation documents requesting comments, with the final versions of the standards normally being accompanied by documents with the basis for conclusions regarding the comments received. There is also the Public Interest Oversight Board (PIOB), an international body responsible for supervising the IAASB, whose aim is to ensure that the IAASB's activities follow due process in seeking the public interest (International Auditing and AssuranceStandards Board - IAASB, 2016).

However, since this public consultation process in the development of standards is, besides being technical, also political, as discussed since Watts and Zimmerman (1978), it is possible that the IAASB has been subject to pressures from certain interest groups while developing their standards, or that it has even to some extent, let itself be captured by those it should regulate, as is conceived by capture theory (Stigler, 1971).

Thus, given that in January 2015 the IAASB issued new standards regarding the publishing of the auditor's report, finalizing the Auditor's Report Project (ARP), which was underway since the elaboration of the academic studies in 2006 and with public consultations carried out since 2009 , in this study we seek to answer the following research question: which interest group (independent auditors or regulatory agencies) carried out the most effective lobbying in audit regulations, regarding the project for altering the standards related to the auditor's report?

The aim of the study is to verify the lobbying carried out by particular interest groups (auditors and regulators) in the due process of regulating auditing activities, within the scope of the IAASB, and in this context to identify the interest group that was most effective in their actions to influence the standard setter. In order to achieve this objective, we analyzed the content of comment letters and applied statistical techniques in order to find which interest group, if any, was most effective in influencing the IAASB.

The project for changing the auditor's report relates to several points and proposes relevant changes, such as the inclusion of the Key Audit Matters (KAM) section to address the specific issues of the audited company and the section on the auditor's judgment regarding the entity's going concern (GC) in addition to the quantitative and qualitative discussion concerning the level of materiality adopted. The relevance of these changes motivated various stakeholders to express their position to the IAASB via comment letters in order to influence the international auditing standard setter to attend to their interests in the final documents.

The use of the term lobbying in this paper does not present any negative connotation linked to illegal acts, as common sense dictates in Brazil. Here, it concerns strategies used by users of accounting information to influence standard setting bodies in defense of their businesses and to maximize their wealth.

Content analysis of the comment letters issued by certain groups, in particular auditors and regulatory bodies, and submitted to the IAASB during the phases of the public consultation process, was the methodology employed in this study, given that although it is not the only method employed by lobbyists, it is a publicly available source widely applied in studies on the topic.

In this sense, Carmo, Ribeiro, and Carvalho (2016) analyzed studies related to lobbying in accounting regulation and concluded that most of the research used content analysis of comment letters as an investigation source and data analysis technique. Georgiou and Roberts (2004) can also be cited in defense of this methodology, having investigated other lobbying strategies besides comment letters, with their results showing that the use of other methods is significantly associated with the use of comment letters.

The relevance of understanding the influences that certain groups can have over the standard setting process in the specific case of the IAASB's context should be noted, since it can be the case that public interest is being substituted for fulfilling the interests of certain groups when setting standards. 
In addition, studies in this area have been more commonly carried out in relation to the accounting standards released by the International Accounting Standards Board (IASB) or Financial Accounting Standards
Board (FASB), whereas here the conclusions obtained in the studies on lobbying in accounting standards are also extended to the development process for auditing standards.

\section{THEORETICAL FRAMEWORK}

Given that the studies in this area have focused on setting accounting standards, this line of investigation is used as the basis for this study's theoretical framework, because there are few studies dedicated to analyzing the influence of interest groups within the scope of auditing standard setters.

The influences of interest groups on standard setters, legislators, and regulators have been the object of study in other areas of knowledge, such as law, economics, and political science. Specifically in the process of developing accounting standards, attempts to influence regulators have been the object of studies from different perspectives. Watts and Zimmerman (1978) already discussed the influence of large corporations over the standards published in the United States, showing that this process is political as well as a product of the market, and that certain groups aim to maximize the utility of the standards in relation to their interests. Regarding to the international standards, Larson (1997) analyzed comment letters issued for projects of the International Accounting Standards Committee (IASC) - the former name of the IASB - and verified that a company's size and its multinational activities are determining factors in its attempts to influence the elaboration of international accounting standards.

After analyzing the evolution of regulations related to disclosure in financial statements, Bertomeu and Magee (2015) concluded that increases in disclosure requirements are slower when the standard setter is less politically influential or when higher disclosure costs imply greater political resistance from the reporting companies.

According to Solomons (1978) and Zeff (2002), the standards are not strictly issued in the public interest or with an eminently technical appreciation of the events and transactions that they aim is to regulate. In reality, they contain a political component, influenced by the interests of certain groups that exercise pressure on the issuing body.

Former studies on lobbying in the elaboration of accounting standards can be divided into three groups, as in the classification proposed by Durocher, Fortin, and Côté (2007) (Table 1).

Table 1

Classification of the studies on lobbying

\begin{tabular}{|c|c|}
\hline Group & Objective \\
\hline $\begin{array}{c}\text { Positive Accounting Theory Group } \\
\text { (PATG) }\end{array}$ & $\begin{array}{l}\text { It seeks to analyze the economic motivations of the managers of } \\
\text { companies that prepare financial statements that support their } \\
\text { participation in the process of elaborating accounting standards } \\
\text { and how these motivations affect their willingness to participate } \\
\text { in the lobbying process, positioning themselves against or in } \\
\text { favor of a particular regulatory proposal for accounting. }\end{array}$ \\
\hline $\begin{array}{l}\text { Economic Theory of Democracy Group } \\
\text { (ETDG) }\end{array}$ & $\begin{array}{l}\text { It investigates the participation of interested parties in general in } \\
\text { the process of lobbying accounting standard setters, with concern } \\
\text { about investigating the motives and characteristics that lead the } \\
\text { interested parties to participate in the process of elaborating } \\
\text { accounting standards, from a perspective of balancing between } \\
\text { the costs and benefits of this participation. }\end{array}$ \\
\hline $\begin{array}{l}\text { Coalition and Influence Group } \\
\qquad(\mathrm{ClG})\end{array}$ & $\begin{array}{l}\text { It concerns the potential coalitions between the interest groups } \\
\text { and their possible influence on the decisions of accounting } \\
\text { regulators, investigating how the various preferences of the } \\
\text { interested parties in the accounting process are related and how } \\
\text { the regulators incorporate these preferences into their process for } \\
\text { elaborating standards. }\end{array}$ \\
\hline
\end{tabular}

Source: Adapted from Durocher, Fortin, Côté (2007). 
As the Positive Accounting Theory Group (PATG) aims to analyze the economic motivations of companies that prepare financial statements that lead them to participate in the process of elaborating accounting standards and the Economic Theory of Democracy Group (ETDG) investigates the motivations and characteristics of the general parties in the process of influencing standard setters, in an analysis of the cost versus benefit relationship of this participation, this study fits into the third group described in Table 1, that is, Coalition and Influence Group (CIG), given that it aims to study the effectiveness of the lobbying strategies employed by auditors and regulators and their coalitions.

Table 2 lists some papers on lobbying in the regulating of accounting standards that can fit into one of the three previously described groups.

Table 2

Studies on lobbying in the process of setting accounting standards

\begin{tabular}{cccc}
\hline Author (year) & Country (regulator) & Objective and method & Results achieved \\
\hline
\end{tabular}

To evaluate, via comment letters submitted by companies, the economic incentives for participating

Watts and Zimmerman (1978) United States (FASB) in the elaboration of accounting standards concerning the effects of changes in the general price level.
The conclusion was that managers have economic incentives for lobbying.

Haring (1979) United States (FASB)

To analyze the association between the opinions of certain interest groups and the positions adopted by the FASB with regards to eight projects.
An association was found between the positions adopted by the FASB and those defended by the biggest auditing and accounting firms in the United States and by the FASB's sponsors and also between the opinions of auditors and those of their clients.
Larson (1997)

International (IASC)

To analyze companies participation determinants in the process of issuing comments on various IASC standard setting processes.
The vast majority of the companies that issued comment letters were among the 500 biggest corporations listed by Forbes magazine and operated internationally.

Georgiou and Roberts (2004) United Kingdom (ASB)

To investigate, via comment letters and a questionnaire, the characteristics of lobbyist and nonlobbyist companies in the process of setting a standard on deferred tax.
Companies against the proposal had a higher probability of having contracts with covenants, and the size of the company increases the tendency to participate in the process.

The main conclusion was that the success of the lobbying is positively associated with the respondent's capacity to convey information and that the lobbyist's credibility and whether it is in a country that adopts IFRS both influence the IASB's decision regarding the final standard. lobbying over five IASB projects, from 2002 to 2004, via analysis of more than 600 comment letters.
They identified that companies, accounting professionals, and local regulators accounted for $83 \%$ of lobbying participation. These groups acted more with regards to recognition and measurement, while users and market supervisors acted more in disclousure. 
Table 2

Cont.

\begin{tabular}{clll}
\hline Author (year) & Country (regulator) & Objective and method & \multicolumn{1}{c}{ Results achieved } \\
\hline Santos and Santos (2014) & International (IASB) & $\begin{array}{l}\text { To identify the determinants of } \\
\text { submitting comment letters as a } \\
\text { lobbying strategy for the IASB's } \\
\text { extractive activities project. }\end{array}$ & $\begin{array}{l}\text { The conclusion was that the oil } \\
\text { company's size increases the } \\
\text { probability of it participating } \\
\text { in the consultation process, } \\
\text { notably in positions against the } \\
\text { proposals for altering IFRS } 6 .\end{array}$ \\
\end{tabular}

ASB = Accounting Standards Board; FASB = Financial Accounting Standards Board;

IASC = International Accounting Standards Committee; IFRS = International Financial Reporting Standards; IASB = International Accounting Standards Board.

Source: Adapted from Carmo, Ribeiro, and Carvalho (2016).

From Table 2 it is worthy of notice that most of the studies used comment letters as an information source and content analysis as a data analysis technique to test their hypotheses, with the conclusions not presenting uniform results and varying according to the project being analyzed, the issuing body, the groups of users selected, and the characteristics studied.

The objective of several studies carried out, see Table 2, was to understand what leads companies to try and influence the standard setting process, explaining how they do so and with which goals. Another focus, such as that presented by Sutton (1984), concerns the identification of the best moment in which the interested party should participate in the standard setting process and what argumentation to use in the attempt to maximize their efforts to influence the issuing body's decisions.

Sutton (1984) argues that the participant will be more effective if it tries toinfluence the standard setter before the $\mathrm{ED}$ is issued. This author also classifies lobbying strategies into direct and indirect, formal and informal, concluding that the choice of method should be analyzed in a case by case basis. He also considers a long-term strategy as the representation of the lobbyist's interests in the structure of the regulatory body, whether at the decision-making level, or in the consultative structure.

As Fogarty (1992) shows, lobbying strategies in accounting regulation can also be analyzed in light of institutional theory, which states that the actions of organizations should be seen as a search for legitimacy in society or to maintain credibility in the eyes of external agents. Kenny and Larson (1993) concluded that organizations such as the IASB aim for their own survival by seeking legitimacy in the eyes of their constituents, and that one of the tools used for this objective is the public consultation process when issuing their documents. Tavares, Paulo, and Anjos (2013) state that a comment letter analysis can be considered a good proxy for the existence of lobbying, since even when attempting to influence by other means firms also submit letters with the aim of legitimizing the process.

Thus, agencies that set accounting standards request comments from differentparticipants in the accounting community, on each one of the phases of their projects, in order to seek this legitimacy and as a survival strategy.

In the case of IAASB, the due process of issuing their standards envisages carrying out public consultation procedures during the development of the documents issued. Within these procedures is the issuing of EDs and Consultation Papers (CPs), with a deadline, for receiving letters from parties interested in the subject to be regulated and discussion of the feedback received in technical meetings with subsequent publication of reasons for the decision to accept or not the suggestions derived from the letters received.

This process creates an environment for the participation of interest groups organized in order to exert political pressure so that the IAASB attends to their proposals and develops standards on auditing and correlated services that serve their particular needs, which are not always aligned with the public interest.

It is therefore to be expected that groups act together to defend common interests - in this study, coalitions between auditors and their national associations interested in protecting auditing professionals from regulatory changes that increase their exposure to litigation or reputational risks, as well as regulators and national standard setters, which have a common motivation for auditing standards to be issued strictly seeking the public interest.

Regarding studies in the area of issuing auditing rules, we point out Jonsson and Svensson (2014), Simnett and Huggins (2014), and Williams and Wilder (2015). Simnett and Huggins (2014) sought to analyze the responses to the Invitation to Comment (ITC) issued by the IAASB regarding the auditor's report in order to determine the level of agreement with the proposed reformulations. The 
results show strong support for improving the disclosure in the auditor's report concerning other information attached to the financial statements and little support regarding the inclusion of additional information in the auditor's report concerning judgments and audit procedures. In addition, evidence was found that North American respondents presented less support for most of the IAASB's proposals than other regions.

Jonsson and Svensson (2014) sought to understand, via content analysis of the comment letters sent to the IAASB in the project for altering the auditor's report, the political process of developing auditing standards, and they concluded that the IAASB needed to address the influence of various interest groups and that not all had their opinions considered. Due to the ambiguous results, they were not able to distinguish groups with more or less effective strategies for lobbying the regulator.

Williams and Wilder (2015) described the feedback paper received in the public consultations of the Public Company Accounting Oversight Board (PCAOB) in the United States during the evolution of the regulatory policy. The authors verified different levels of support or opposition to the standards issued by the PCAOB among the interest groups evaluated and concluded that the agency revises almost half of its positions after analyzing the comments received in consultation processes.

\section{PROJECT FOR REFORMULATING THE STANDARDS RELATED TO THE AUDITOR'S}

\section{REPORT}

The auditor's report has been object of various changes to its content and format. At the beginning of this activity, it was a more individualized document, with information on how each audit was conducted, until reaching its current form, with a standardized language and format.

The first international document purposed to standardize the reports issued by auditors was International Audit Guide (IAG) n. 13, published in 1983 by the International Auditing Practices Committee (IAPC), the IAASB's predecessor. This standard was revised in 1989 and again in 1993. Currently, the standard that addresses the auditor's report is ISA 700, which underwent revisions in 2001,2004, and lastly in 2008, in the project for clarifying the ISAs. All these changes were made aiming to further harmonize the audit reports issued in different countries, as well as using clear language for financial statement users.

Besides ISA 700, there are requirements regarding the audit report in other standards issued by the IAASB, notably in ISAs 705 and 706, which address, respectively, modifications in the auditor's opinion and emphasis of matter and other matter paragraphs.

After the events that resulted in the 2008 financial crisis, the work of auditors was again criticized, and the audit report issued regarding financial statements was the target of questioning by various users regarding its usefulness and informative capacity (IFAC, 2011).

In this context, the IAASB itself determined the elaboration of studies to identify users' perceptions concerning the auditor's report and concluded that the standardized report had limited usefulness due to only informing of the existence or not of some modification, as well as differences being detected between the expectations of auditors and other financial statement users regarding the auditor's responsibilities (IFAC, 2015a).

At the end of 2010, the IAASB decided that it should explore ways of modifying the auditor's report, notably because external bodies, such as the International Organization of Securities Commissions (IOSCO), the European Commission, and some national auditing regulators, were already evaluating ways of improving the role of auditors and their reports (IAASB, 2010).

Hence, the IAASB issued a $\mathrm{CP}$ regarding the options for altering the auditor's report and increasing its value for users, aiming to capture the views of various stakeholders with regards to the relevance and usefulness of the auditor's report, whether there are differences in expectations, and to what extent, information gap between its users, in addition to obtain views regarding options to improve its quality, relevance, and value, as well as regarding the implications and challenges of such changes. This CP made it clear that it was based on the assumption that the audit scope should remain the same (IFAC, 2011).

In a meeting that occurred in December of 2011, the IAASB discussed the feedback received in 82 comments to the $\mathrm{CP}$, as well as in presential meetings (round tables) and outreaches carried out by various regulators and supervisors. In the letters received, there was strong support for the need to improve the communicative power of the auditor's report, however maintaining the binary nature of the opinion (modified or not) without the inclusion of "cliché" language that could divert the reader's attention concerning the issue. There was also significant support for the need for more transparency regarding the auditing process and that the scope of the audit should not be changed, but rather that the way 
of working and the opinion issued should be reported (IFAC, 2011).

After a detailed analysis of the responses to the items contained in the CP, the IAASB decided it was important to elaborate a project to revise the auditor's report in line with the support received by users regarding the options for changes suggested in its consultation document. In this project, issues for which there was the greatest demand from the respondents would be addressed, such as including in the report information about management judgments and disclosure regarding how the auditor evaluated quantitatively and qualitatively the materiality, among other topics (IFAC, 2011).

In June 2012, the IAASB issued an invitation to comment (ITC) regarding improvements in the auditor's report. This document presented the IAASB's views concerning the changes that it understood were needed and the reasons for each change suggested, as well as presenting a model of what the new report would be like (IAASB, 2012a).

Initially, what stands out is the fact that the aspects of the quantitative and qualitative disclosure regarding materiality, addressed in the $\mathrm{CP}$, no longer appeared in the ITC, although it has been cited as information that could act in reducing the information and expectation gap between auditors and other users of their reports. The main changes presented in the ITC in relation to the auditor's report currently used are described in Table 3.

Table 3

Changes suggested on the auditor's report in the Invitation to Comment

\begin{tabular}{ll}
\hline Item & \multicolumn{1}{c}{ Suggested change } \\
\hline Auditor's opinion & $\begin{array}{l}\text { It moves from the end to the beginning of the report, } \\
\text { giving more prominence to the opinion. It refers to } \\
\text { the explanatory notes as an integral part of } \\
\text { the statements. }\end{array}$ \\
\hline Going concern & $\begin{array}{l}\text { Inclusion of a specific section about the topic in the auditor's } \\
\text { report, which makes conclusions about the appropriate use of the } \\
\text { going concern assumption and the declaration that based on the } \\
\text { auditing procedures carried out no condition or event was } \\
\text { identified that puts this use in doubt. }\end{array}$ \\
\hline
\end{tabular}

Creation of a section in which the auditor comments on the most important topics for the users to understand the financial statements

Auditor commentary or the audit. Areas of significant management judgment, unusual transactions, and significant auditing material, including critical judgments and difficulties in carrying out the work, are items suggested for inclusion in this section.

Name of the engagement partner

Other information

Declaration of complying with ethical standards

Responsibility of the auditor, the management, and the governance
Disclosure of the name of the engagement partner, as well as the name of the firm, as already required.

The auditor should declare, in a specific section of the report, that he/ she has read other information included in the annual report and that he/she did not find any material inconsistencies in relation to the financial statements.

Inclusion of a declaration of complying with ethical standards, including in relation to auditor independence.

Expansion of the section to clarify the responsibilities of these participants in the process of preparing, supervising, and auditing the financial statements, as well as improving the users' understanding regarding the auditor's responsibility in relation to fraud, internal controls, and accounting policies, among others.

Source: Adapted from IAASB (2012a). 
As shown in Table 3, substantial changes to the auditor's report were proposed. The period for comments on this material closed on October 8, 2012, and 165 comments were received (IAASB, 2012b).

Besides the description of what, how, and why the changes were proposed and the presentation of a model report contemplating these changes, the ITC raised a series of 18 questions for the respondents.

After an analysis and discussion of the answers to the ITC, in June 2013 the IAASB issued the ED of the new versions of the standards impacted by the auditor's report project, including: the standard related to GC
- ISA 570; the standard related to the communication with the governance - ISA 260; the standards related to modifications and emphasis in the auditor's report - ISAs 705 and 706; and a new standard, ISA 701 - Key Audit Matters in the Independent Auditor's Report, which addresses questions related to the section of the report that in the ITC was called Auditor Commentary (IAASB, 2013).

The main differences between the suggestions presented in the ITC and what is described in the ED are listed in Table 4.

\section{Table 4}

Changes suggested in the Exposure Drafts for the auditor's report

\begin{tabular}{ll}
\hline \multicolumn{1}{c|}{ Item } & \multicolumn{1}{c}{ Suggested change } \\
\hline Name of the engagement partner & $\begin{array}{l}\text { Name of the engagement partner will be required } \\
\text { only in audit reports of listed companies, and no } \\
\text { longer in all audits, as foreseen in the ITC. }\end{array}$ \\
\hline $\begin{array}{l}\text { Ethical and } \\
\text { independence requirements }\end{array}$ & $\begin{array}{l}\text { Improvement of the declaration of complying with ethical } \\
\text { and independence standards in relation to } \\
\text { the model suggested in the ITC. }\end{array}$ \\
\hline Auditor commentary (KAM) & $\begin{array}{l}\text { The KAM section substituted the Auditor Commentary section } \\
\text { and was now only required for listed companies, while in } \\
\text { the ITC a more comprehensive concept was required } \\
\text { for public interest entities. }\end{array}$ \\
\hline Report structure & $\begin{array}{l}\text { The order of presentation of certain elements of the report } \\
\text { becomes non-obligatory. }\end{array}$
\end{tabular}

ITC = Invitation to Comment; KAM = key audit matters.

Source: Adapted from the IAASB (2013).

Considering the changes carried out, summarized in Table 4, the ED raised questions for the respondents regarding the KAM section, GC, ethical and independence requirements, disclosure of the engagement partner's name, changes in ISA 700, and the obligation of the order of presentation of the sections (IAASB, 2013).

There was a significant change with regards to the KAM concept between what was presented in the ITC and the ED version, since initially the section should contain important information for the user's understanding of the financial statements, while the ED addresses material that in the auditor's judgment is most significant in the auditing of the financial statements. In addition, in the ED the IAASB addressed the discussion about suppressing the emphasis of matter paragraphs and those on other information via their inclusion in the KAM section and questioned the respondents on whether the distinction between these sections of the auditor's report is clear in the proposed changes to the standards (Jonsson \& Svensson, 2014).

In the GC section, the ED altered the paragraph of the model report present in the ITC, which addressed identifying material uncertainty that puts in doubt the company's ability to maintain its operations, including a sentence that reputes to the management the initial responsibility for such identification.

The period for receiving comments in this last phase of public consultation closed on November 22, 2013, and 139 comments were received (IAASB, 2014). These comment letters are what constituted the target population for the content analysis of this study.

In a meeting in September 2014, the IAASB approved the final version of the standards altered by the Auditor Reporting Project (ARP), as well as the new ISA 701 standard and the conforming amendments to some others. These standards were published in January 2015 with an effective date for audits of financial statements ending on or after December 15, 2016 (IFAC, 2015b).

Table 5 shows the main changes noted in this final phase of development of the standards in relation to the $\mathrm{ED}$, as according to the document with the basis for the conclusion published by the IAASB (2015). 
Table 5

Changes in the final standards in relation to the Exposure Drafts

\begin{tabular}{|c|c|}
\hline Item & Suggested change \\
\hline KAM & $\begin{array}{l}\text { International Standard on Auditing (ISA) } 701 \text { also applicable when } \\
\text { required by law or national standard and for voluntary communication by the auditor. }\end{array}$ \\
\hline $\begin{array}{l}\text { Guidance on } \\
\text { KAM }\end{array}$ & $\begin{array}{l}\text { More application material and details about the use of the KAM } \\
\text { section. }\end{array}$ \\
\hline Going concern & $\begin{array}{c}\text { End of the requirement of a specific section, with it only being } \\
\text { applicable in cases in which there are material uncertainties } \\
\text { relating to the topic. }\end{array}$ \\
\hline Name of the engagement partner & $\begin{array}{l}\text { Inclusion of application material to clarify the exceptions regarding the inclusion of the } \\
\text { name of the engagement partner in the case of threats to his/her personal safety. }\end{array}$ \\
\hline Ethical and independence requirements & $\begin{array}{l}\text { Instead of reference to a specific standard, identification is required } \\
\text { of the jurisdiction of origin of the ethical requirements or reference to } \\
\text { the international code of ethics issued by the International } \\
\text { Ethics Standards Board for Accountants (IESBA). }\end{array}$ \\
\hline $\begin{array}{l}\text { Structure of the } \\
\text { report }\end{array}$ & $\begin{array}{l}\text { Requirement for the opinion and basis for the opinion to obligatorily be at the } \\
\text { beginning of the report. The other sections can be ordered as determined by each } \\
\text { jurisdiction, with the example in the standard being the format that the International } \\
\text { Auditing and Assurance Standards Board (IAASB) considers the best practice. }\end{array}$ \\
\hline Declaration of responsibilities & $\begin{array}{l}\text { The auditor's responsibilities may not be included in the report, } \\
\text { but instead a reference to the website of the authority that describes } \\
\text { these responsibilities or as an attachment to the report. }\end{array}$ \\
\hline
\end{tabular}

$K A M=$ key audit matters.

Source: Adapted from the IAASB (2015).

It is therefore observed that significant changes in several aspects of the auditor's report were proposed by the IAASB in this project and that these proposals were altered by the IAASB itself during the public consultation phases.

\section{METHODOLOGY}

\subsection{Definition of the Data Collection and Analysis Techniques}

Considering what is described in section 3 regarding development of the standards and given that the main discussions and changes in the report, within the model initially presented in the ITC, the ED, and the final version, was concentrated on topics related to the auditor commentary (KAM) section and the GC, these are the objects of this article, in relation to the comments sent by auditors (and their professional associations) versus regulators' (and national standard setters') opinions.

The responses from the interest groups to the questions asked by the IAASB in the ED were collected from the IAASB website, specifically regarding the questions presented in Table 6, selected due to the delimitation of the topics mentioned in the previous paragraph, excluding question number 4 , given that this question asks for the respondent to select more or less useful examples concerning KAM among those presented in the ED, which makes classifying the responses in accordance with the proposed methodology unviable. 
Table 6

Questions in the Exposure Drafts whose answers will be analyzed in this study

\begin{tabular}{cll}
\hline Question & Item & \multicolumn{1}{c}{ Description } \\
\hline Q1 & KAM & $\begin{array}{l}\text { Do users of the audited financial statements believe that the introduction of a new } \\
\text { section in the auditor's report describing the matters the auditor determined to be of most } \\
\text { significance in the audit will enhance the usefulness of the auditor's report? If not, why? }\end{array}$
\end{tabular}

Q2 KAM

Do respondents believe the proposed requirements and related application material in proposed ISA 701 provide an appropriate framework to guide the auditor's judgment in determining the key audit matters? If not, why? Do respondents believe the application of proposed ISA 701 will result in reasonably consistent auditor judgments about what matters are determined to be the key audit matters? If not, why?

Q3 KAM

Do respondents believe the proposed requirements and related application material in proposed ISA 701 provide sufficient direction to enable the auditor to appropriately consider what should be included in the descriptions of individual key audit matters to be communicated in the auditor's report? If not, why?

Do respondents agree with the approach the IAASB has taken in relation to key audit matters for entities for which the auditor is not required to provide such communication - that is, key audit matters may be communicated on a voluntary basis but, if so,

Q5 KAM proposed ISA 701 must be followed and the auditor must signal this intent in the audit engagement letter? If not, why? Are there other practical considerations that may affect the auditor's ability to decide to communicate key audit matters when not otherwise required to do so that should be acknowledged by the IAASB in the proposed standards?

Do respondents believe it is appropriate for proposed ISA 701 to allow for the possibility that the auditor may determine that there are no key audit matters to communicate? (a) If so, do respondents agree with the proposed requirements addressing such Q6 KAM circumstances? (b) If not, do respondents believe that auditors would be required to always communicate at least one key audit matter, or are there other actions that could be taken to ensure users of the financial statements are aware of the auditor's responsibilities under proposed ISA 701 and the determination, in the auditor's professional judgment, that there are no key audit matters to communicate?

Do respondents agree that, when comparative financial information is presented, the Q7 KAM auditor's communication of key audit matters should be limited to the audit of the most recent financial period in light of the practical challenges explained in paragraph 65 ? If not, how do respondents suggest these issues could be effectively addressed?

Q8 KAM

Do respondents agree with the IAASB's decision to retain the concepts of Emphasis of Matter paragraphs and Other Matter paragraphs, even when the auditor is required to communicate key audit matters, and how such concepts have been differentiated in the Proposed ISAs? If not, why?

Do respondents agree with the statements included in the illustrative auditor's reports relating to: (a) The appropriateness of management's use of the going concern basis of accounting in the preparation of the entity's financial statements? (b) Whether the auditor has identified a material uncertainty that may cast significant doubt on the entity's ability to concern, including when such an uncertainty has been identified (see the Appendix of proposed ISA 570 (Revised)? In this regard, the IAASB is particularly interested in views as to whether such reporting, and the potential implications thereof, will be misunderstood or misinterpreted by users of the financial statements?

What are respondents' views as to whether an explicit statement that neither management nor the auditor can guarantee the entity's ability to continue as a going concern should be required in the auditor's report whether or not a material uncertainty has been identified?

$I A A S B=$ International Auditing and Assurance Standards Board; ISA = International Standard on Audit; KAM = key audit matters.

Source: Adapted from the IAASB (2013). 
The answers to the questions formulated by the IAASB were classified by one of the researchers, following the model applied by Simnett and Huggins (2014), so that each one of the answers regarding the most critical topics - GC and KAM - was evaluated according to the agreement or disagreement concerning the question formulated on a 5-point scale, this being: $1=$ disagreement with the IAASB's proposal; 2 = disagreement with reservations; $3=$ ambivalent/uncertain; $4=$ support with reservations; $5=$ support the IAASB's proposal.

With the aim of minimizing the bias in the classification carried out, a second researcher independently classified one sample of letters, obtaining more than $90 \%$ agreement in the classifications carried out by the first researcher, thus enabling the use of that classification in an unbiased way.

After the classification, the answers were summarized by interest group in order to analyze the group's approval in relation to each element. Given that the use of the 5-point scale involves ordinal variables, the use of measures such as mean and deviations is not appropriate, as according to Fávero, Belfiore, Silva, and Chan (2009). Thus, by using favorability (answers 4 and 5), it is possible to order the respondents according to their attitudes regarding the object (Sanches, Meireles \& De Sordi, 2011).

Subsequently, the distributions of the interest groups' responses were compared using ANOVA to verify the existence or not of statistically significant differences between the groups' answers. Identifying significant differences between the groups, it was also verified whetherthe auditor' and regulators' positions with regards to the ARP were significantly different, and for this case Scheffés post-hoc test was used.

The assumptions of normality and homoscedasticity of the ANOVA residuals were satisfied. According to the Jarque-Bera normality test (chi-squared $=4.58$ and $\mathrm{p}$-value $=0.1012$ ), the null hypothesis of normality was not rejected, while using the Breusch-Pagan/Cook-Weisberg test the null hypothesis of constant variance between the groups was also not rejected, with a chi-squared equal to 0.88 and $p$-value of 0.349 .

In addition, the lobbying effectiveness of each interest group was evaluated in order to identify who obtained the most success in the IAASB's recommendations, that is, who exercised the greatest power of influence over the standard setter in terms of their interests being met.

\subsection{Sample Characteristics}

The comments letters received in the three phases of the consultation carried out by the IAASB were classified by group and their distribution is presented in Table 7.

\section{Table 7}

Distribution of the comment letters received by the International Auditing and Assurance Standards Board by group

\begin{tabular}{lccr}
\hline \multicolumn{1}{c}{ Group } & $\begin{array}{c}\text { CP } \\
\mathbf{n}(\mathbf{\%})\end{array}$ & $\begin{array}{c}\text { ITC* } \\
\mathbf{n}(\%)\end{array}$ & $\begin{array}{c}\text { ED* } \\
\mathbf{n}(\mathbf{\%})\end{array}$ \\
\hline $\begin{array}{l}\text { Professional associations } \\
\text { and bodies }\end{array}$ & $29(35)$ & $44(26)$ & $43(30)$ \\
\hline Auditing firms & $10(12)$ & $24(15)$ & $16(12)$ \\
\hline Regulators and supervisors & $12(15)$ & $17(10)$ & $16(12)$ \\
\hline Public sector organizations & $7(9)$ & $12(7)$ & $14(10)$ \\
\hline Investors and analysts & $6(7)$ & $13(8)$ & $12(9)$ \\
\hline National standard setters & $6(7)$ & $13(8)$ & $12(9)$ \\
\hline Individuals & $5(6)$ & $13(8)$ & $7(5)$ \\
\hline Preparers & $4(5)$ & $11(7)$ & $9(6)$ \\
\hline Academics & $0(0)$ & $10(6)$ & $9(6)$ \\
\hline Those charged with governance & $3(4)$ & $165(100)$ & $1(1)$ \\
\hline Total & $82(100)$ & $139(100)$ \\
\hline
\end{tabular}

$C P=$ Consultation Paper; $E D=$ Exposure Drafts; $I T C=$ Invitation to Comment.

* in the IAASB's official statistics, the comment letters received from the Institute of Independent Auditors of Brazil (IBRACON) were not officially computed in the ITC phase, nor those from the Institute of Chartered Accountants of Jamaica (ICAJ) in the ED phase, because they were received after the public consultation deadline. These letters, however, were used in this study.

Source: Elaborated by the authors based on the documents available from IFAC (2015b). 
Analyzing the distribution of the letters by respondent group shown in Table 7, the predominance of auditors whether via national associations or auditing firms - is noted in relation to the other parties interested in the auditing work. Regulators and supervisors, as well as standard setters, have a significantly smaller participation than auditors in all consultation phases.

With relation to the evolution of the comments, the expressive increase (100\%) between the quantity of answers to the CP and to the ITC may be related to the early stage and unclear focus of the initial document, whose impacts were not clear to the interested parties. In the ITC, the proposed changes in the auditor's report started to be outlined and the users of the standards related to the work of auditors expressed in greater quantity.

In the final phase of participation via comment letters, in the ED, the participation was a little lower than in the ITC, which may be in line with the conclusions of Sutton
(1984), who indicates that lobbying is more widely used in the initial stages of standard development, given that the regulators's perceptions regarding the subject would still be taking form.

Of the 165 letters received by the IAASB in response to the ITC, 68 relate to auditing firms and their professional organizations, while 17 were issued by regulators and supervisors, and 13 by national standard setters, which are the interest groups whose responses were analyzed in this study.

In the ED phase, 59 letters were sent by auditing firms and their professional organizations, while 16 regulators and supervisors and 12 national standard setters participated in the public consultation process.

The IAASB also presents the distribution of the comment letters received by respondent geographical location, as listed in Table 8 .

Table 8

Distribution of the comment letters received by the International Auditing and Assurance Standards Board by geography

\begin{tabular}{|c|c|c|c|}
\hline Category & $\begin{array}{c}\text { CP } \\
\text { n (\%) }\end{array}$ & $\begin{array}{l}\text { ITC* } \\
\text { n (\%) }\end{array}$ & $\begin{array}{c}\text { ED* } \\
\text { n (\%) }\end{array}$ \\
\hline Europe & $28(34)$ & $47(29)$ & $38(27)$ \\
\hline Asia Pacific & $16(20)$ & $38(23)$ & $29(21)$ \\
\hline North America and Caribbean & $15(18)$ & $37(23)$ & $27(19)$ \\
\hline Global entities & $17(21)$ & $26(16)$ & $28(20)$ \\
\hline Middle East and Africa & $5(6)$ & $12(7)$ & $12(9)$ \\
\hline South America & $1(1)$ & $5(2)$ & $5(4)$ \\
\hline Total & $82(100)$ & $165(100)$ & $139(100)$ \\
\hline
\end{tabular}

$C P=$ Consultation Paper; $E D=$ Exposure Drafts; $I T C=$ Invitation to Comment.

* = in the IAASB'S official statistics, neither the comment letters received from IBRACON in the ITC phase nor those received from ICAJ in the ED phase were computed because they were received after the deadline for the public consultation. These letters, however, were used in this study.

Source: Elaborated by the authors based on the documents available from IFAC (2015b).

Regarding the geographical distribution of the respondents, as shown in Table 8, the European entities were consistently the most participative during all the phase of the process, followed by Asia Pacific (including
Oceania), North America and Caribbean, and global entities, with these three groups having quite similar levels of participation.

\section{RESULTS}

\subsection{Comparison of the Interest Groups' Positions}

Table 9 presents the frequency distribution of the answers to each question presented in the ED and that were selected to be used as a basis for the research, considering the 5-point scale varying from "disagree" to "agree". 
Table 9

Frequency distribution of the answers by question

\begin{tabular}{|c|c|c|c|c|c|c|c|}
\hline Question & $\begin{array}{c}\text { Disagrees } \\
\text { (1) }\end{array}$ & $\begin{array}{l}\text { Disagrees with } \\
\text { reservations (2) }\end{array}$ & Ambivalent (3) & $\begin{array}{l}\text { Agrees with } \\
\text { reservations (4) }\end{array}$ & $\begin{array}{l}\text { Agrees } \\
\text { (5) }\end{array}$ & $\begin{array}{l}\text { Did not } \\
\text { answer }\end{array}$ & Total \\
\hline Q1 & 1 & 6 & 10 & 42 & 20 & 7 & 86 \\
\hline Q2 & 0 & 22 & 5 & 47 & 5 & 7 & 86 \\
\hline Q3 & 3 & 27 & 2 & 34 & 13 & 7 & 86 \\
\hline Q5 & 3 & 7 & 4 & 35 & 19 & 18 & 86 \\
\hline Q6 & 3 & 4 & 1 & 25 & 39 & 14 & 86 \\
\hline Q7 & 1 & 3 & 1 & 22 & 42 & 17 & 86 \\
\hline Q8 & 3 & 6 & 2 & 44 & 23 & 8 & 86 \\
\hline Q9 & 10 & 32 & 11 & 21 & 8 & 4 & 86 \\
\hline Q10 & 20 & 25 & 6 & 17 & 13 & 5 & 86 \\
\hline Total & 44 & 132 & 42 & 287 & 182 & 87 & 774 \\
\hline
\end{tabular}

Source: Elaborated by the authors based on the documents available from IFAC (2015b).

From the data in Table 9 it is possible to verify that among the 86 respondents that are the basis for this study due to them forming part of the selected interest groups, there was a predominance of positions in favor of the IAASB's proposals (around 68\% answered 4 or 5) as opposed to positions against (around 26\% answered 1 or 2$)$.

Evaluating the questions $(\mathrm{Q})$ individually, more than 90\% favorability is noted for Q6, Q7, and Q8, which address, respectively, the possibility of the auditor communicating that there is no KAM to report, that the KAM section is limited to the most recent period, and of maintaining the concepts of emphasis of matter paragraphs and other information paragraphs.

In turn, the questions with less favorability were Q9 and Q10, which address changes to the auditor's report with regards to the GC of the audited company's businesses, and which were answered 1 and 2 by more than $50 \%$, indicating that most of the participants in the public consultation were not yet satisfied with the changes carried out by the IAASB with regardsto the way auditors should report their responsibilities in relation to the GC of the audited company's businesses.

Table 10 presents the frequency distributions considering the selected interest groups.

Table 10

Frequency distribution of the answers by interest group

\begin{tabular}{|c|c|c|c|c|c|c|c|}
\hline Interest group & $\begin{array}{l}\text { Disagrees } \\
\text { (1) }\end{array}$ & $\begin{array}{l}\text { Disagrees with } \\
\text { reservations (2) }\end{array}$ & $\begin{array}{l}\text { Ambivalent } \\
\text { (3) }\end{array}$ & $\begin{array}{l}\text { Agrees with } \\
\text { reservations (4) }\end{array}$ & $\begin{array}{l}\text { Agrees } \\
\text { (5) }\end{array}$ & $\begin{array}{l}\text { Did not } \\
\text { answer }\end{array}$ & Total \\
\hline Auditors & 6 & 23 & 6 & 67 & 36 & 6 & 144 \\
\hline Associations & 21 & 68 & 25 & 123 & 103 & 38 & 378 \\
\hline Regulators & 10 & 26 & 2 & 49 & 20 & 37 & 144 \\
\hline Standard Setters & 7 & 15 & 9 & 48 & 23 & 6 & 108 \\
\hline Total & 44 & 132 & 42 & 287 & 182 & 87 & 774 \\
\hline
\end{tabular}

Sources: Elaborated by the authors based on the documents available from IFAC (2015b).

By analyzing the frequency of the answers by interest group, as shown in Table 10, it is verified that regulators form the group with the greatest percentage of positions against the IAASB's proposals (33.6\% answered 1 or 2 ), while auditors form the group that agreed most with the changes to the standards ( $74.6 \%$ answered 4 or 5$)$.
With the aim of showing this difference in positions, some example of answers to question 6 are presented, which addresses the possibility of the auditor stating that there is no KAM to report, and it is possible to verify a clear difference in position between auditors and standard setters: 
Answer from Deloitte Touche Tohmatsu: "Yes, DTTL concurs with the IAASB that proposed ISA 701 should allow for the possibility that the auditor may determine there are no KAMs to be communicated."

Answer from the Australian Auditing and Assurance Standards Board: "The AUASB disagrees with the proposal to allow for the possibility that the auditor may determine that there are no key audit matters to communicate. The AUASB believes that the auditor should be required to always communicate at least one KAM."

Table 11 details the result obtained in relation to the approval for each one of the questions object of this study, considering the interest groups and their coalitions.

Table 11

Favorability rating by interest group and by coalition

\begin{tabular}{|c|c|c|c|c|c|c|c|}
\hline \multirow{3}{*}{ Questions } & \multicolumn{5}{|c|}{ Interest groups (\%) } & \multirow{2}{*}{\multicolumn{2}{|c|}{$\begin{array}{c}\text { Coalitions (\%) } \\
\text { (favorability) }\end{array}$}} \\
\hline & \multicolumn{5}{|c|}{ (favorability) } & & \\
\hline & Auditors & $\begin{array}{l}\text { Professional } \\
\text { associations }\end{array}$ & Regulators & $\begin{array}{l}\text { Standard } \\
\text { setters }\end{array}$ & Total & $\begin{array}{l}\text { Auditors and } \\
\text { associations }\end{array}$ & $\begin{array}{l}\text { Regulators and } \\
\text { standard setters }\end{array}$ \\
\hline $\begin{array}{c}\text { Q1 } \\
(\mathrm{n}=79)\end{array}$ & 93.4 & 81.3 & 94.9 & 70.7 & 84.9 & 84.8 & 85.0 \\
\hline $\begin{array}{c}\text { Q2 } \\
(\mathrm{n}=79)\end{array}$ & 93.4 & 70.5 & 76.2 & 82.5 & 78.3 & 77.9 & 79.3 \\
\hline $\begin{array}{c}\text { Q3 } \\
(\mathrm{n}=79)\end{array}$ & 95.1 & 74.0 & 64.1 & 63.6 & 76.1 & 80.7 & 63.9 \\
\hline $\begin{array}{c}\text { Q5 } \\
(\mathrm{n}=68)\end{array}$ & 91.8 & 83.8 & 100.0 & 93.3 & 89.0 & 86.4 & 95.9 \\
\hline $\begin{array}{c}\text { Q6 } \\
(\mathrm{n}=72)\end{array}$ & 92.5 & 98.1 & 87.9 & 95.9 & 95.5 & 96.5 & 92.7 \\
\hline $\begin{array}{c}\text { Q7 } \\
(\mathrm{n}=69)\end{array}$ & 100.0 & 94.8 & 100.0 & 95.9 & 96.8 & 96.4 & 97.6 \\
\hline $\begin{array}{c}\text { Q8 } \\
(\mathrm{n}=78)\end{array}$ & 94.9 & 93.2 & 93.2 & 91.5 & 93.3 & 93.7 & 92.5 \\
\hline $\begin{array}{c}\text { Q9 } \\
(\mathrm{n}=82)\end{array}$ & 32.5 & 46.8 & 76.1 & 70.6 & 53.7 & 43.0 & 73.8 \\
\hline $\begin{array}{c}\text { Q10 } \\
(\mathrm{n}=81)\end{array}$ & 52.5 & 72.2 & 0.0 & 63.6 & 60.2 & 67.5 & 38.2 \\
\hline Total & 86.5 & 81.0 & 81.3 & 82.7 & 82.4 & 82.6 & 82.0 \\
\hline
\end{tabular}

Source: Elaborated by the authors based on the documents available from IFAC (2015b).

Analyzing the data displayed in Table 11, it is verified that there is slight supremacy in relation to the favorability in the auditors' answers to the questions, showing that in the ED the items questioned already contained changes suggested by the participants in previous stages of the public consultation, meaning there was a predominance of answers in favor of the IAASB's propositions. However, in the findings of Simnett and Huggins (2014), who analyzed the previous public consultation phase (ITC), there was supremacy of the regulators.

It is also verified in Q5 (which addressed the cases in which the auditor is not obliged to report KAM, but when deciding to do so should follow the requirements of ISA 701 and indicate this intention in the contract letter) that the regulators present $100 \%$ approval of the IAASB's proposal, while the professional associations presented a lower ratio of $83.8 \%$ favorability, which may show the concern of professional associations about possible difficulties in the users of statements from non-listed entities understanding the new section of the report, or them misinterpreting it, which can be observed in passages from some letters below:

Answer from the Argentinean Federation of Professional Councils for Economic Sciences (FACPCE): “We prefer 
to implement the approach proposed by the IAASB in stages, being firstly binding on listed companies, and to postpone the voluntary application until the market gathers sufficient experience and adapts to the changes they introduce."

Answer from the Italian Accounting Reviser Association (ASSIREVI): "With respect to the possibility to include the KAM voluntarily when agreed by the parties as per paragraph 30 of the Proposed ISA 700, we feel that this would lead to an undue different level of information being provided to users."

Aiming to verify the existence of statistically different positions per question, Table 12 presents the results of the ANOVA carried out.

Table 12

Results of the ANOVA

\begin{tabular}{|c|c|c|c|c|c|c|}
\hline Question & & $\begin{array}{l}\text { Sum of the } \\
\text { squares }\end{array}$ & df & Mean square & Z-score & Sig. \\
\hline \multirow{3}{*}{ Q1 } & Between groups & 2.134 & 3 & 0.711 & 0.881 & 0.455 \\
\hline & In the groups & 60.549 & 75 & 0.807 & & \\
\hline & Total & 62.684 & 78 & & & \\
\hline \multirow{3}{*}{ Q2 } & Between groups & 3.895 & 3 & 1.298 & 1.399 & 0.250 \\
\hline & In the groups & 69.598 & 75 & 0.928 & & \\
\hline & Total & 73.494 & 78 & & & \\
\hline \multirow{3}{*}{ Q3 } & Between groups & 6.360 & 3 & 2.120 & 1.453 & 0.234 \\
\hline & In the groups & 109.412 & 75 & 1.459 & & \\
\hline & Total & 115.772 & 78 & & & \\
\hline \multirow{3}{*}{ Q5 } & Between groups & 7.328 & 3 & 2.443 & 2.242 & $0.092 *$ \\
\hline & In the groups & 69.731 & 64 & 1.090 & & \\
\hline & Total & 77.059 & 67 & & & \\
\hline \multirow{3}{*}{ Q6 } & Between groups & 11.426 & 3 & 3.809 & 3.957 & $0.012^{* *}$ \\
\hline & In the groups & 65.449 & 68 & 0.962 & & \\
\hline & Total & 76.875 & 71 & & & \\
\hline \multirow{3}{*}{ Q7 } & Between groups & 0.127 & 3 & 0.042 & 0.056 & 0.982 \\
\hline & In the groups & 49.032 & 65 & 0.754 & & \\
\hline & Total & 49.159 & 68 & & & \\
\hline \multirow{3}{*}{ Q8 } & Between groups & 0.467 & 3 & 0.156 & 0.152 & 0.928 \\
\hline & In the groups & 75.533 & 74 & 1.021 & & \\
\hline & Total & 76.000 & 77 & & & \\
\hline \multirow{3}{*}{ Q9 } & Between groups & 4.757 & 3 & 1.586 & 1.053 & 0.374 \\
\hline & In the groups & 117.499 & 78 & 1.506 & & \\
\hline & Total & 122.256 & 81 & & & \\
\hline \multirow{3}{*}{ Q10 } & Between groups & 25.913 & 3 & 8.638 & 4.680 & $0.005^{* * *}$ \\
\hline & In the groups & 142.112 & 77 & 1.846 & & \\
\hline & Total & 168.025 & 80 & & & \\
\hline
\end{tabular}

$* * *, * *, *=1,5$, and $10 \%$ level of significance, repectively.

Source: Elaborated by the authors based on the documents available from the IFAC (2015b).

It is possible to identify that there are significant differences between the interest groups at a level of $1 \%$ in the answers to Q10, which addresses the inclusion in the auditor's report, in the section about GC, of a declaration that neither the management nor the auditors can guarantee the company's ability to continue its businesses, even if there is no material uncertainty regarding the subject, which indicates the regulators' concern regarding the responsibility of the auditor's report to make the auditor's responsibility in relation to the company's GC 
clear to the user, something that was even the target of stakeholder criticism during the 2008 crisis, in which some companies entered into bankruptcy without there being any emphasis or modification related to the continuity of their businesses in their published audit reports regarding financial statements from the previous financial period.

Also statistically significant, but at a level of $5 \%$, was Q6, which addressed the possibility of the auditor not reporting KAM, which according to certain regulators would not be appropriate, since the auditor is expected to be more intensely dedicated to at least one area of the financial statements.

Marginally, statistical significance at a level of $10 \%$ was found in Q5, which addresses the application of the requirements of ISA 701 and indications in the contract letter of cases in which the auditor is not obliged to report KAM but decides to do so, which, as already mentioned in the analysis of the favorability rating, may show the concern of professional associations about the users of financial statements of non-listed entities misinterpreting the KAM paragraphs.

Given that the ANOVA was applied to all the groups of respondents, in addition, Scheffés post-hoc test was also carried out, in which it was possible to confirm that there is a significant difference in position between regulators and auditors with regards to Q6 ( $\mathrm{p}$-value = 0.019 ) and Q10 (p-value =0.005). Concerning Q5, in which the ANOVA indicated a marginally significant difference between the groups, Scheffés post-hoc test did not indicate any statistical significance, as is verified in Table 13.

Table 13

Post-hoc analysis of the differences found

\begin{tabular}{|c|c|c|c|c|c|c|c|c|}
\hline \multirow[b]{2}{*}{ Group } & \multicolumn{4}{|c|}{ Q5 } & \multicolumn{4}{|c|}{ Q6 } \\
\hline & Auditors & Associations & $\begin{array}{l}\text { Standard } \\
\text { Setters }\end{array}$ & Regulators & Auditors & Associations & $\begin{array}{l}\text { Standard } \\
\text { Setters }\end{array}$ & Regulators \\
\hline Auditors & - & & & & - & & & \\
\hline Associations & 0.57 & - & & & 0.99 & - & & \\
\hline Issuers & 0.62 & 0.99 & - & & 0.99 & 0.98 & - & \\
\hline Regulators & 0.16 & 0.70 & 0.76 & - & $0.019^{* *}$ & $0.045^{* *}$ & $0.074^{*}$ & - \\
\hline \multirow[b]{2}{*}{ Group } & \multicolumn{4}{|c|}{ Q10 } & & & & \\
\hline & Auditors & Associations & $\begin{array}{l}\text { Standard } \\
\text { Setters }\end{array}$ & Regulators & & & & \\
\hline Auditors & - & & & & & & & \\
\hline Associations & 0.71 & - & & & & & & \\
\hline Issuers & 0.85 & 0.99 & - & & & & & \\
\hline Regulators & $0.005^{* * *}$ & 0.204 & 0.191 & - & & & & \\
\hline
\end{tabular}

Note: regulators vs. auditors in bold.

$* * *, * *, *=1,5$, and $10 \%$ level of significance, respectively.

Source: Elaborated by the authors.

Aiming to verify the existence of significant differences in the interest groups' positions, and considering their coalitions, these being (i) auditors and their associations and (ii) regulators and notional standard setters, the Pearson independence chi-squared test wasapplied. The results are presented in Table 14. 


\section{Table 14}

Results of the Pearson independence chi-squared test

\begin{tabular}{ccccc}
\hline & & Coalitions & \\
\cline { 2 - 4 } & DF & $\mathbf{X}^{\mathbf{2}}$ & p-value & 0.237 \\
\hline Q1 & 4 & 5.528 & 0.900 \\
\hline Q2 & 3 & 0.583 & 0.497 \\
\hline Q5 & 4 & 3.374 & 0.405 \\
\hline Q6 & 4 & 4.010 & 0.260 \\
\hline Q7 & 4 & 5.273 & 0.902 \\
\hline Q8 & 4 & 1.051 & 0.867 \\
\hline Q10 & 4 & 1.269 & $0.072^{*}$ \\
\hline
\end{tabular}

$D F=$ degree of freedom.

$* * *, * *, *=1,5$, and $10 \%$ level of significance, respectively.

Source: Elaborated by the authors based on the documents available from IFAC (2015b).

In the result, Q5 and Q6 cease to present any significant difference in position, as in previous tests, and Q10 becomes significant only at a level of $10 \%$, given that in these matters the standard setters present a mean position similar to the auditors and their professional associations and not to the regulators, as can be seen in Table 11 .

On the other hand, there is now a significant difference at a level of $10 \%$ with regards to Q9, which addresses including paragraphs in the auditor's report about using the going concern assumption. In this case, the regulators and standard setters present a more favorable position than the auditors and their associations, a result that is also aligned with the findings of Simnett and Huggins (2014).

In the cases of Q6 and Q10, the auditors' (or their coalitions') position was more in favor of the IAASB's suggestions. Specifically regarding Q6, the difference observed in the results may be explained by a possible intention of the auditors not to report KAM in certain situations, using this passage of the standard as support, while in the regulators' evaluation there appears to be a greater need to make it clear that critical topics should be reported, independently of the size, sector, or any other characteristic of the audited company.

With relation to Q10, the more favorable position of the auditors may be explained by the recurrent questions from regulators and investors about the auditor's reports issued in years prior to company bankruptcies not mentioning the problem that caused them. A statement in the auditor's report stating that neither the management nor the auditors can guarantee the continuity of the audited company's businesses could be used as a way of reducing the auditors' litigation risk and possible questions from investors that feel adversely affected by opinions without modification related to going concern followed by bankruptcy of the audited company's businesses.

In Q9, the regulators' (and standard setters') position was more aligned with theIAASB's suggestion to include declarations regarding GC than that of the auditors (and their associations); in the same sense as in the analysis related to Q10, the regulators revealed having the expectation that by including declarations about GC in their report, even in cases in which no material uncertainty was found with regards to the topic, the auditors would be more skeptical in their evaluation.

Given that it is normal to subdivide auditors between the biggest international auditing firms (commonly called the Big 4) and other firms, since there are conflicting interests between these groups in some topics, such as auditor rotation, certification requirements, and aspects linked to auditing quality, we carried out chi-squared tests between these two subgroups and the inexistence of any significant difference in position between the Big4 and the other auditors was verified for every question evaluated in this study. This may be explained by the fact that the questions presented in the ED are sensitive for the whole category of auditors in terms of exposure to litigation risks and reputational risks, which are areas in which the interests of the whole category are common. 


\subsection{Analysis of the Effectiveness of the Interest Groups' Lobbying}

For the questions with a significant difference in position between the interest groups (Q5, Q6, and Q10) or coalitions (Q9 and Q10), we evaluated the decision taken by the IAASB in relation to the matter consulted in these items, with the aim of verifying what position was most effective with regards to the lobbying strategy.

With relation to the topic discussed in Q5, the IAASB maintained the requirements that ISA 701 should be followed, however it withdrew from including the paragraph in ISA 210 in which it is explicitly required that reference be made in the auditors' contract letter to the expectation of adding the KAM section in their report. Thus, the IAASB sought to accommodate both the regulators' preference, so that the requirements of the standard are followed when the auditor has voluntarily decided to report KAM, and the auditors' and their associations' concerns regarding the obligation of foreseeing in the contract letter that the format of the report could include the section with the main auditing matters.

With regards to Q6, the regulators were less favorable (87.9\%) than the auditors $(92.5 \%)$, with three of the 10 regulators that answered the question being against the IAASB's proposal,while of the 15 responding auditors only one was against the permission to not report KAM. The IAASB's final position regarding the possibility of there not being any KAM to report was maintained in the final version of the auditing standard, with the inclusion of more guidance concerning what the auditor should do in these situations, and so the auditors' opinion prevailed over that of the regulators.

For the subject of Q9, the coalition of regulators and standard setters presented more answers agreeing with the proposal than disagreeing, with $73.8 \%$ approval, while the coalition of auditors and professional associations gave more unfavorable answers to what was presented in the $\mathrm{ED}$ ( $43 \%$ approval).

In the final standards, the IAASB made changes with regards to the topic, presenting as justification that there are discussions underway within the scope of the IASB regarding $\mathrm{GC}$, and therefore that the specific section about the topic will only be required in the auditor's report when material uncertainty is identified; it also altered the text in the paragraph about the audited entity's management using the continuity assumption.

Regarding Q10, the coalition of regulators and standard setters was less in favor (38.2\%) than the coalition of auditors and their associations (67.5\%). Individually, it is noted that all 14 regulators that answered the question positioned themselves against the IAASB's proposal.

In the final standards that address the topic, the IAASB decided to alter the requirement to include this declaration in the specific section on GC - this section ceased to exist - and transfer it to the section on the auditor's responsibilities. In addition, the declaration text was altered, substituting the passage "neither the management nor the auditor can guarantee the company's ability to continue its operations" for "future conditions or events may cause the continuity of the company's businesses to cease". On this question, the regulators' opinion prevailed in relation to that of the auditors, given the changes processed by the IAASB in response to the criticisms received in the public consultation process.

These results partially confirm the findings of Williams and Wilder (2015) with regards to the changes made by the standard setting body to its positions after analyzing the comment letters issued by the interest groups during the public consultation process. This is consistent with institutional theory in that the auditing standard setter aims to maintain its power in the eyes of external agents by considering their participation in the process of developing the standards issued and by seeking to accommodate the different interests that exist.

\section{CONCLUSIONS}

The main goal was to analyze whether there is difference between auditors and regulators views, and their respective coalitions, in the last phase of public consultation for the IAASB's Improving the Auditor's Report project in an attempt to influence the standards setfor auditing activities, as well as evaluating the effectiveness of the strategy of these interest groups submitting comment letters.

The positions of the interest groups and their coalitions in the 86 comment letters submitted to the IAASB were analyzed, verifying that, as in Simnett and Huggins (2014), in the previous consultation phase of this project, for most of the questions, there was no significant difference in position between the interest groups.

However, it was observed that in some questions analyzed there is a significant difference in position with regards to the IAASB's proposals. In these cases, the auditors' position was more favorable than that of the regulators, which shows that the groups acted to influence the regulator to attend to their distinct interests 
in these questions, which address the possibility of the auditor determining that there are no key audit matters to report and of statements related to the GC of the audited company, respectively.

Regarding the effectiveness of the lobbying strategy of the interest groups that formed part of the scope of this research, the results are mixed, with the IAASB attending to the different interests in the final version of the standards impacted for this project, which shows that the entity was subject to pressures from different interest groups involved in the auditing standard development process.

Tavares et al. (2013) refer to the statement from Riahi-Belkaouri (2004), who says that the enactment of a standard is a social choice that forces regulators to adopt a political process with the aim of accommodating various interests, including their own; that is, consistent with institutional theory, the regulator is motivated to adopt strategies with an aim to retaining its power and credibility in the community or seeking the reelection of its members.

The predominant idea in Peltzman (1976) is that no economic interest captures regulators in isolation and that the aim of these entities is essentially to maximize their political support in order to guarantee their permanence in the role. For this they need to balance their own interests and the distribution of benefits between interest groups in an optimal manner.

In this context, it seems evident that the IAASB acted to attend in some way to the various groups participating in the standard setting process, accommodating their interests and at the same time guaranteeing the legitimacy of its position as standard setter, but without being captured by any interest group or their coalitions.

As a contribution, this paper presents an extension to the line of research regarding the international auditing standard setting process, given that the current studies concentrate on accounting standards, as well as presenting an innovative methodology for classifying the responses in relation to the binary position (agree or disagree) that is generally adopted in other studies on lobbying carried out in Brazil.

As a suggestion for future investigations, the position of the other interest groups that responded to this project could be evaluated, thus contemplating $100 \%$ of the letters sent. Alternatively, the responses to other relevant projects recently developed or in development by the IAASB could be analyzed to verify whether the results are consistent with those presented here. In addition, there could be a focus on a qualitative analysis of the comment letters, in an attempt to evaluate whether the technical rigor of the answers and the relevance of the respondent are predominant in the regulator's decision.

In terms of limitations of this study, despite taking care to validate the classification used via an independent assessment, the researchers' judgment regarding the classification of the participants' answers in the IAASB consultation process can be mentioned, given that the answers are not always clear, making the work of determining their classification complex, as well as the delimitation of the interest groups, which did not correspond to $100 \%$ of the respondents, with the IAASB possibly also being influenced by groups whose answers werenot analyzed.

In addition, the lobbying strategies used by the interest groups present other initiatives, such as participation in IAASB meetings in the public sessions to discuss the projects during the public audience period, funding of regulatory bodies, actions via associations and class entities, and board or committee or supervisory body member nominations, among others, which have the potential to influence the final version of the standards.

\section{REFERENCES}

Bertomeu, J., \& Magee, R. P. (2015). Political pressures and the evolution of disclosure regulation. Review of Accounting Studies, 20(2), 775-802.

Carmo, C. H. S., Ribeiro, A. M., \& Carvalho, L. N. G. (2016). Lobbying na regulação contábil: desenvolvimentos teóricos e pesquisas empíricas. Revista Universo Contábil, 12(2), 59- 79.

Durocher, S., Fortin, A., \& Côté, L. (2007). Users' participation in the accounting standard- setting process: a theory-building study. Accounting, Organization and Society, 32(1-2), 29-59.

Fávero, L. P., Belfiore, P., Silva, F. L. \& Chan, B. L. (2009). Análise de dados: modelagem multivariada para tomada de decisões. Rio de Janeiro, RJ: Campos.
Fogarty, T. J. (1992). Financial accounting standards setting as an institutionalized action field: constraints, opportunities and dilemmas. Journal of Accounting and Public Policy, 11(4), 331-355.

Georgiou, G., \& Roberts, C. B. (2004). Corporate lobbying in the UK: an analysis of attitudes towards the ASB's 1995 deferred taxation proposals. The British Accounting Review, 36(4), 441453.

Hansen, T. B. (2011). Lobbying of the IASB: an empirical investigation. Journal of International Accounting Research, 10(2), 57-75.

Haring, J. R., Jr. (1979). Accounting rules and "the accounting establishment”. Journal of Business, 52(4), 507-519. 
International Auditing and Assurance Standards Board. (2010). Auditor reporting - issues and IAASB working group proposals. Retrieved from http://www.iaasb.org/system/files/meetings/ files/5854_1.pdf

International Auditing and Assurance Standards Board. (2012a). Invitation to Comment.

Improving the auditor's reporting. Retrieved from https://www. ifac.org/system/files/publications/files/Auditor_Reporting Invitation_to_Comment-final_0.pdf

International Auditing and Assurance Standards Board. (2012b). Summary on key improvements included in the Invitation to Comment. Retrieved from http://www.iaasb.org/system/files/ meetings/files/20121210-IAASB-Agenda_Item_6-AR_Coverfinal.pdf

International Auditing and Assurance Standards Board. (2013). Exposure Draft. Reporting on audited financial Statements: proposed and new revised international standards on audit. Retrieved from https://www.ifac.org/publications-resources/ reporting-audited- financial-statements-proposed-new-andrevised-international.

International Auditing and Assurance Standards Board. (2014). Auditor reporting cover final.

Retrieved from http://www.iaasb.org/system/files/meetings/ files/20140317-IAASB-Agenda_Item_4-Auditor_Reporting_ Cover-final.pdf.

International Auditing and Assurance Standards Board. (2015). Basis for conclusions.

Reporting on audited financial statements - new and revised auditor reporting standards and related conforming amendments. Retrieved from https://www.iaasb.org/system/ files/publications/files/Basis\%20for\%20Conclusions\%20-

\%20Auditor\%20Reporting\%20-\%20final.pdf.

International Auditing and Assurance Standards Board. (2016). About IAASB. Retrieved from http://www.iaasb.org/aboutiaasb

International Federation of Accountants. (2011). Enhancing the value of auditor reporting: exploring options for change. Retrieved from http://www.ifac.org/system/files/publications/ exposure-drafts/CP_Auditor_Reporting-Final.pdf.

International Federation of Accountants. (2015a). 2014 annual review - Leveraging on our global advantage. Retrieved from http://www.ifac.org/publications-resources/2014-ifac-annualreview

International Federation of Accountants. (2015b). Auditor reporting: project status. Retrieved from https://www.iaasb.org/ projects/auditor-reporting

Jonsson, T., \& Svensson, K. (2014). The process of changing the audit report in an international context (Master's Dissertation).
Lund University, Suécia.

Jorissen, A., Lybaert, N., Orens, R., \& Van Der Tas, L. (2012). Formal participation in the IASB's due process of standard setting: a multi-issue/multi-period analysis. European Accounting Review, 21(4), 693-729.

Kenny, S. Y., \& Larson, R. K. (1993). Lobbying behavior and the development of international accounting standards: the case of IASC's joint venture project. European Accounting Review, 2(3), 531-554.

Larson, R. K. (1997). Corporate lobbying of the International Accounting Standards Committee. Journal of International Financial Management and Accounting, 8(3), 175- 203.

Peltzman, S. (1976). Toward a more general theory of regulation. The Journal of Law \& Economics, 19(2), 211-240.

Riahi-Belkaoui, A. (2004). Accounting theory. ( $5^{\text {a }}$ ed.). Londres: Thomson.

Sanches, C., Meireles, M., \& Sordi, J. D. (2011). Análise qualitativa por meio da lógica paraconsciente: método de interpretação e síntese de informação obtida por escalas Likert. Anais do III Encontro de Ensino e Pesquisa em Administração e Contabilidade (EnEPQ), João Pessoa, PB/Brasil.

Santos, O. M., \& Santos, A. (2014). Lobbying na regulação contábil: evidências do setor petrolífero. Revista Contabilidade \& Finanças, 25(65), 124-144.

Simnett, R., \& Huggins, A. (2014). Enhancing the auditor's report: to what extent is there support for the IAASB's proposed changes? Accounting Horizons, 28(4), 719-747.

Solomons, D. (1978). The politicization of accounting. Journal of Accountancy, 146(5), 65-72. Stigler, G. J. (1971). The Theory of Economic Regulation. The Bell Journal of Economics and

Management Science, 2(1), 3-21.

Sutton, T. G. (1984). Lobbying of accounting standard-setting bodies in the U.K. and the U.S.A.: a downsian analysis. Accounting, Organizations and Society, 9(1), 81-95.

Tavares, M. F. N., Paulo, E., \& Anjos, L. C. M. dos (2013). Contribuições ao Exposure Draft revenue for contracts with costumers: análise das opiniões das firmas sobre a obrigação de desempenho onerosa. Revista de Contabilidade do Mestrado em Ciências Contábeis da UERJ, 18(2), 14-27.

Watts, R. L., \& Zimmerman, J. L. (1978). Towards a positive theory of the determination of accounting standards. The accounting Review, LIII(1), 112-134.

Williams, L. T., \& Wilder, W. M. (2015). Constituent feedback on audit regulatory policy: an examination of $P C A O B$ comment letters. Retrieved from https://www2.aaahq.org/AM2015/ abstract.cfm?submissionID $=1229$

Zeff, S. A. (2002). "Political” lobbying on proposed standards: a challenge to the IASB. Accounting Horizons, 16(1), 43-54. 